\title{
Studies of the Perception of Respondents regarding KVK Training Intervention in Agriculture
}

\author{
Sabyasachi Karak ${ }^{1}$, Subhajit $\operatorname{Roy}^{1}$ and Siddhartha Dev Mukhopadhyay ${ }^{2}$ \\ ${ }^{1}$ Department of Agricultural Extension, Faculty of Agriculture, Bidhan Chandra Krishi \\ Viswavidyalaya, Mohanpur, Pin code- 741252, Nadia, West Bengal, India \\ ${ }^{2}$ Department of Agricultural Extension, Palli Siksha Bhavana, Institute of Agriculture, Visva- \\ Bharati University, Sriniketan- 731236, Birbhum, West Bengal, India \\ *Corresponding author
}

\section{A B S T R A C T}

\begin{tabular}{|l|}
\hline Key w or d s \\
Perception, \\
Training, \\
Interventions \\
\hline Article Info \\
\hline Accepted: \\
12 January 2019 \\
Available Online: \\
10 February 2019 \\
\hline \hline
\end{tabular}

The present study was executed in Palli Siksha Bhavana, Institute of Agriculture, VisvaBharati University in the year 2016-17. KVK generally deals with training programmes related to needy areas to be served to both men and women. The Subject Matter Specialists are deputed to other KVKs, Agricultural Universities, ICAR institutes and other training institutes to orient themselves with the subject. The objective was to study the perception of respondents regarding KVK intervention in agriculture. As Ban and Hawkins (2000) define perception as the process by which we receive information or stimuli from our environment and transform it into psychological awareness. It is interesting to see that people infer about a certain situation or phenomenon differently using the same or different sets of information. In the present research work the word "Perception" refers to the understanding/comprehension of farmers make about different components of training like the extent of awareness, knowledge and skill developed through KVK training, few broad areas have been considered on which trainings have been imparted by Nadia Krishi Vigyan Kendra.

\section{Introduction}

Krishi Vigyan Kendras generally deal with training programmes related to needy areas to be served to both men and women. The type of courses covered are usually package of practices for various cereals, pulses, oilseeds, vegetable and fruit crops, fertilizer management, plant protection, farm mechanization, care and feeding of animals, sheep and goat keeping, poultry farming, pisciculture, irrigation and water management, soil and moisture conservation, income generating activities, farm planning, marketing of produce etc. To impart training efficiently, KVKs very often engaged more specialised persons. The training programmes are further intended to cover backward areas and weaker sections on the priority basis. But how can be the impact of KVK's can be measured? Understandably it's a huge institution spread over the country training on 
public fund. Has it show positive impacts in terms of well trained farming community able to able latest agricultural technologies in their field which in turn expected to increase the production and productivity of crops and lands. But there was an attempt for changing agricultural matrix of the country through application of $\mathrm{S}$ and $\mathrm{T}$ inputs; farmers' perception played an important role in accepting and adopting those $\mathrm{S}$ and $\mathrm{T}$ inputs in their field. Resultantly it is fund that almost there are no dearth improved technologies but the adoption rate of the same is not up to the level of expectation. Some logic is also pertinent in case of KVK's efforts in imparting awareness, knowledge and skill among farmers on various aspect of farming. How do farmers perceive the KVK's as well as the usefulness of their efforts. To ascertain the extent of awareness, knowledge and skill developed through KVK training, few broad areas have been considered on which trainings have been imparted. These are Knowledge and Skill development about agricultural technologies; Knowledge and Skill development for Income generating activities; Knowledge and Skill development about Better livestock Management; Knowledge and Skill development about Farm Mechanisation; Knowledge and Skill development about New Technologies; Knowledge and Skill development about Improvement of overall Socio-economic Condition. Under each broad area sets of statements have been framed.

\section{Materials and Methods}

Research is a systematic attempt to obtain answers to meaningful questions about phenomena or events through the application of scientific procedure. It is an objective, empirical, logical analysis and recording of controlled observations that may lead to the development of generalisations, principles or theories resulting to some extent in prediction and control of events out of consequences in case of specific phenomena. Research is therefore, scientific and as such not satisfied with isolated facts, but seeks to integrate and systematise its findings. The chapter deals with the research methods and procedures followed by the researcher to analyze the problem in the course of investigation. The entire discussions have been made under the following sub-themes.

\section{Plan of work}

Considering wide and varied application of the study, it was felt that detailed survey of all aspects related to the objectives should be framed for the study. Keeping the stipulated period in view, the area of investigation, sample size, problem and method of analyses of data, a rough plan was prepared prior to actual investigation and finalized subsequently.

\section{Research design}

A research design is the programme that guides the researcher in the process of collecting, analysing and interpreting observations to draw inferences. Keeping in view the objective of the study, the researcher tried to include qualitative and behavioural attributes in the study. The present research study comes within the purview of survey research mainly of "Ex-post facto" in nature. In the light of the objectives and scope of the study, decisions were taken on the techniques of investigation, research materials and tools to be used and patterns of statistical analysis to be incorporated.

\section{Locale of the study}

The study was proposed to be conducted in three blocks in Nadia district in West Bengal. Under these three blocks six villages are taken for this research. 


\section{Sampling procedure}

Purposive as well as simple random sampling techniques were adopted for the study. For selection of district and block purposive sampling techniques was adopted and in case of selection of respondent's simple random sampling technique was taken up covering to a total sample of 120 respondents to be selected as respondent for the present study a farmer was required to be attending $\mathrm{KVK}$ training at least for last three years.

\section{Sampling Frame}

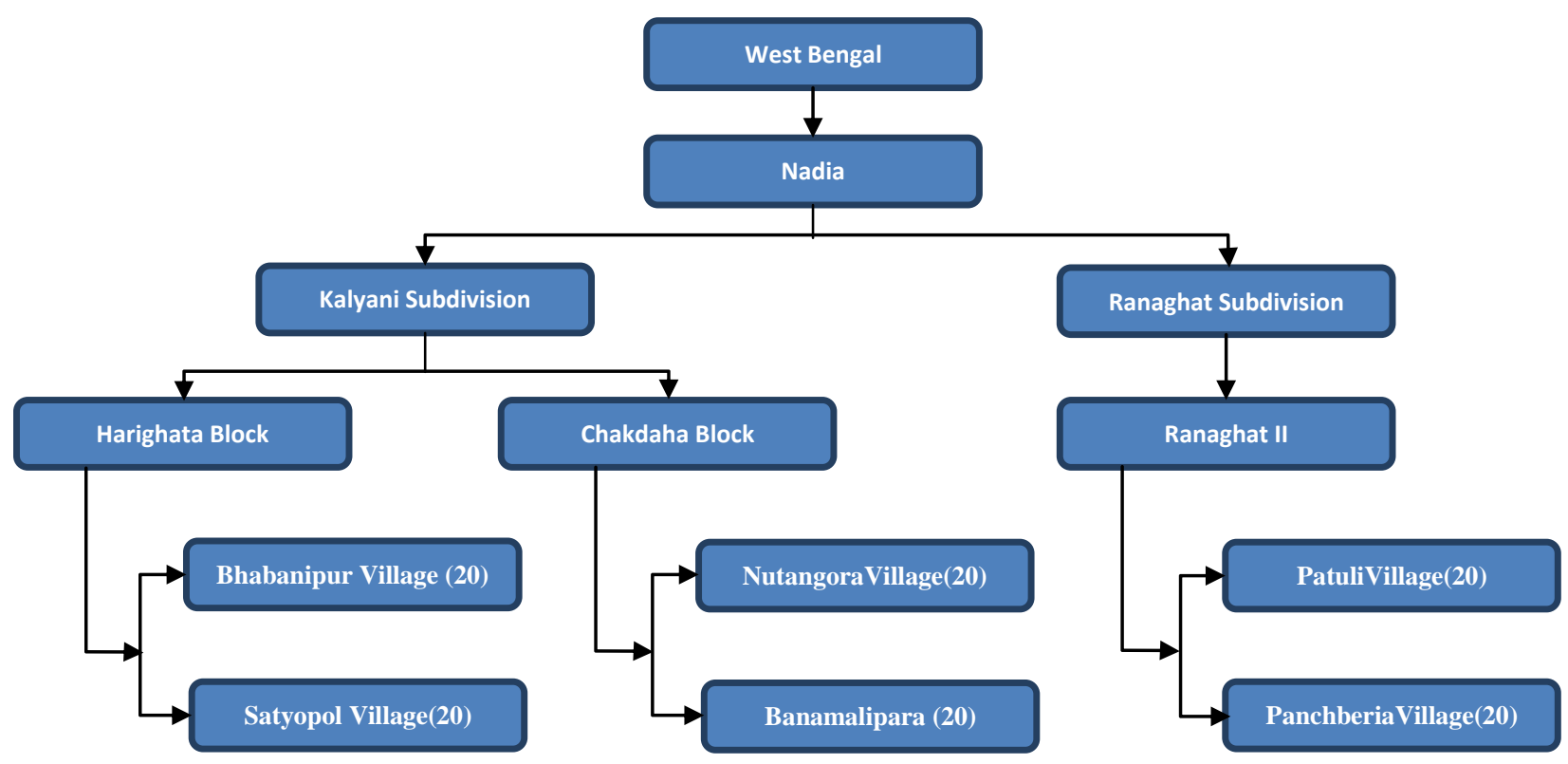

\section{Statistical analysis}

\section{Percentage}

Percentage was used in description analysis for making simple comparison between two responses. For calculating percentage, the frequency of a particular cell was multiplied by 100 and divided by the total number of respondents in the particular category to which the cell belonged.

Percentage $=\frac{\text { Number of respondents in a cell }}{\text { Total number of respondents }} \times 100$

\section{Mean score}

It is defined as the sum of observations divided by number of observations. Mean is the simplest and relatively stable measure of central tendency. It is used summarily on the essential features of a series and in enabling data to be compared. Mean is better than other averages especially in social and economic studies where direct quantitative measurements are possible.

$\operatorname{Mean}(\bar{x})=\frac{1}{n} \sum_{i=1}^{n} X i$

Where

$\mathrm{x}=$ the symbol used for mean, $\Sigma=$ Summation, $x_{i}=$ Values of $i^{\text {th }}$ item, $n=$ Number of respondents.

\section{Calculation of score index}

It is also another score gap analysis where the obtainable scores of each of the respondents on a variable were calculated to categorize them in to four categories as given below, 
ScoreIndex $=\left(\frac{\text { Score }_{\text {obtained }}}{\text { Score }_{\text {Max }}}\right) \times 100$

\section{Factor analysis}

Factor is a method of multivariate analysis and is often used as a method of data reduction. The different steps of factor analysis have been employed in study are as follows:

i. Correlation Matrix is used as a primary data for factor extraction

ii. Variables which have Eigen value more than 1 are selected as components.

iii. Varimax type of Rotation of orthogonal Rotation with Kaiser Normalization is applied as a method of rotation.

\section{Regression analysis}

$\mathrm{Y}=\mathrm{a}+\mathrm{b}_{1} \mathrm{x}_{1}+\mathrm{b}_{2} \mathrm{x}_{2}+\ldots \ldots \ldots \ldots \ldots \ldots \ldots+\mathrm{b}_{\mathrm{n}} \mathrm{x}_{\mathrm{n}}$

Where,

$\mathrm{Y}=$ dependent variable, $\mathrm{a}=\mathrm{a}$ constant, $\mathrm{b}_{1}=$ partial regression coefficient, $\mathrm{x}_{1}=$ independent variables, $\mathrm{n}=$ total numbers of independent variables.

\section{Multiple Regression Analysis}

$\mathrm{Y}=\mathrm{a}+\mathrm{b}_{1} \mathrm{X}_{1}+\mathrm{b}_{2} \mathrm{X}_{2}+----------+\mathrm{b}_{\mathrm{k}} \mathrm{X}_{\mathrm{k}}$

Where,

$\mathrm{a}$ is the intercept (i.e. the value of $\mathrm{Y}$ )

When all $X$ are 0 and $b$ (1------k) are the partial regression coefficients associated with the independent variables $\mathrm{Xi}$, represents the amount of change in the $\mathrm{Y}$ for each unit in $\mathrm{Xi}$.

\section{Step wise multiple regression}

The step wise regression procedure computes a sequence of regression equations, at each step adding and deleting independent variables. Let the procedure starts with an explanatory variable, say $\mathrm{X} 1$, then it enters $\mathrm{X} 2$ using the forward selection procedure. After X2 is entered, it looks at X1 and decided whether to retain it or not by looking at F-value of X1. If it is retained, it enters the next variables, say X3. After X3 is entered, it looks again at the $\mathrm{F}$-values for variables, $\mathrm{X} 1$ and $\mathrm{X} 2$, and deletes any variables which are super flows. The procedure requires F-values. The F-value which determines the addition of variables and the F-value which determines the variables to delete.

\section{Results and Discussion}

Perception of respondents about KVK training in increasing knowledge and skill about agricultural technologies

Table 1 represents the distribution of respondents against their PI regarding increase in knowledge and skill about agricultural technologies. From the table it can be observed that in Haringhata (17) and Ranaghat (16) block majority of the respondents had semi-medium level of perception about increase in knowledge and skill followed by high level of perception (12 and 16 respectively).

In case of Chakdaha block majority of the respondents had high perception about their increase in knowledge and skill through KVK trainings (35).

Taking all the blocks together it was found that majority of the respondents had high perception about increase in knowledge and skill through KVK training followed by semimedium and medium level of perception.

\section{Perception of respondents about KVK training for income generating activity}

Table 2 represents the distribution of respondents against their PI about KVK 
training for income generating activity. From the table it can be observed that in Haringhata (14) and Ranaghat (15) and Chakdaha (18) block majority of the respondents had high perception about KVK training in this regard.

In case of Haringhata (14) and Ranaghat (13) block the next majority group had medium level of perception while considering Chakdaha (14) block majority had semi medium level of perception in this regard. Taking all the blocks together it was found that majority of the respondents had high of perception about KVK training for income generating activity index group followed by semi-medium and medium index group respectively.

\section{Perception of respondents about KVK} training for better livestock management

Table 3 represents the distribution of respondents against their PI about KVK training helpful for farm mechanization. From the table it can be observed that in Haringhata (19) and Chakdaha (30) block majority of the respondents had high perception about KVK training for farm mechanization followed by semi-medium level of perception (17, 10respectively).

While in case of Ranaghat (21) block it can be observed that majority of the respondents had under semi medium level of perception followed by high (12) level. Taking all the blocks together it was found that majority of the respondents had high level perception about KVK training for farm mechanization followed by semi-medium and medium level of perception.

\section{Perception of respondents about KVK training on new technology}

Table 4 represents the distribution of respondents against their PI about KVK training on new technologies. From the table it can be observed that in Ranaghat (19) and Chakdaha (22) block majority of the respondents had high perception of getting new technologies from KVK training followed by semi-medium level of perception $(15,15$ respectively).

It is also found that in case of Haringhata block majority of the respondents had semimedium (15) level of perception in this regard followed by high (14) level of perception.

Taking all the blocks together it was found that majority of the respondents had high of perception regarding getting new technologies form KVK training followed by semi-medium and medium index group.

Perception of respondents about KVK training for overall improvement of socioeconomic condition

Table 5 represents the distribution of respondents against their PI with regard to KVK training for overall improvement of socio-economic condition.

From the table it can be observed that in Haringhata (20) and Chakdaha (26) block majority of the respondents had high perception about KVK training in this regard followed by semi-medium (15 and 13 respectively) level of perception.

And in case of Ranaghat block it can be observed that majority of the respondents had semi-medium (18) level of perception followed by high (13) perception level index.

Taking all the blocks together it was found that majority of the respondents had high perception about KVK training for overall improvement of socio-economic conditions or the respondents followed by semi medium and medium level of perception. 
Association between changes in knowledge with other independent variables

To ascertain this association change in knowledge in crop production, horticulture and income generation technologies change index have been considered as the dependent variables for all three cases. Variables like, Extent of training received in seed science (X1), Extent of training received in agronomy (X2), Extent of training received in horticulture (X3), Extent of training received in plant protection (X4) and Extent of training received in animal husbandry (X5), Perception of Respondents about KVK Training in Increasing Knowledge and Skill about Agricultural Technologies (X6), Perception of Respondents about KVK Training for Income Generating Activity (X7),Perception of Respondents about KVK Training for Better Livestock management (X8), Perception of Respondents about KVK training for Farm Mechanization (X9), Perception of Respondents about KVK training on New Technology (X10), Perception of Respondents about KVK training for overall Improvement of SocioEconomic Condition (X11) have been taken as the independent variables.

Multiple regression and stepwise regression (wherever necessary) were conducted. Results are presented in following tables.

\section{Change index knowledge in crop production technologies}

\section{Regression analysis change in knowledge in crop production technologies}

From table 6 it can be observed that only two variables, namely, Extent of training received in Seed science $\left(\mathrm{x}_{1}\right)$ and Extent of training received in Agronomy $\left(\mathrm{X}_{2}\right)$ had positive and significant association with change in knowledge index. The model only explained
$32.83 \%$ of total variance as observed from Adjusted $\mathrm{R}^{2}$ value.

To have more accurate prediction stepwise regression (forward selection method) was also conducted and result is presented in table 6.1. From the table it can be observed that only two variables, namely, Extent of training received in Seed science and Extent of training received in Agronomy were retained, both were found having significant positive relation with change in knowledge in crop production technologies.

\section{Change index knowledge in horticultural technologies}

\section{Regression analysis change in knowledge in horticultural technologies}

From the table 7 it can be observed that only two variables, namely, Extent of training received in Seed science $\left(x_{1}\right)$, extent of training received in Animal husbandry $\left(\mathrm{X}_{5}\right)$ and extent of training received in Perception of respondents about KVK training on New Technology $\left(\mathrm{X}_{10}\right)$ had positive and significant association with change in knowledge index. The model only explained $47.92 \%$ of total variance as observed from Adjusted $\mathrm{R}^{2}$ value.

To have more accurate prediction stepwise regression (forward selection method) was also conducted and result is presented in table 7.1. From the table it can be observed that only five variables, namely, extent of training received in Seed science, extent of training received in Animal husbandry, extent of training received in Animal husbandry, perception of respondents about KVK training for Income Generating Activity, perception of respondents about KVK training on New Technology and Perception of Respondents about KVK training for overall Improvement of Socio- Economic condition were retained, both were found having significant positive 
relation with change in knowledge in horticultural technologies.

\section{Change index knowledge in income} generating activities

Regression analysis change in knowledge in income generating activities

From the table 8 it can be observed that only two variables, namely, Extent of training received in Horticulture $\left(\mathrm{x}_{3}\right)$, extent of training received in plant protection $\left(\mathrm{X}_{4}\right)$ and extent of training received in agronomy $\left(\mathrm{X}_{2}\right)$ had positive and significant association with change in knowledge index. The model only explained $52.37 \%$ of total variance as observed from Adjusted $\mathrm{R}^{2}$ value.

To have more accurate prediction stepwise regression (forward selection method) was also conducted and result is presented in table 8.1. From the table it can be observed that only four variables, namely, Extent of training received in Horticulture, extent of training received in Plant protection, Extent of training received in Agronomy and Perception of respondents about KVK training in Increasing Knowledge and Skill about Agricultural Technologies were retained, both were found having significant positive relation with change in knowledge in income generating activities.

Ascertaining the association of change in adoption of technologies with other independent variables

For this section, like change in knowledge portion, three broad aspects like, Crop production technologies, Horticulture production technologies and Income generating activities have been considered as dependent variables. Same set of independent variables have been considered as dependent variables. Multiple regression and stepwise regression have been conducted. The results are presented below.

Multiple regression analysis for change in adoption crop production technologies

From the table 9 it can be observed that four independent variables, namely Extent of training received in seed science $\left(\mathrm{X}_{1}\right)$, Extent of training received in animal husbandry $\left(\mathrm{X}_{5}\right)$, Perception of Respondents about KVK Training in Increasing Knowledge and Skill about Agricultural Technologies $\left(\mathrm{X}_{6}\right)$, Perception of Respondents about KVK Training for Better Livestock management $\left(\mathrm{X}_{8}\right)$ had significant and positive association with the change in adoption of crop production technologies.

Step wise regression results as depicted in table 9.1 showed that two variables only retained in the model, having significant positive association with the change in adoption pattern of crop production technologies. The analysis explained $72.54 \%$ of the total variance.

\section{Multiple regression analysis for change in} adoption horticultural technologies

From the table 10 it can be observed that four independent variables, namely, Extent of training received in horticulture, extent of training received in agronomy $\left(\mathrm{X}_{2}\right)$, Perception of Respondents about KVK Training for Better Livestock management $\left(\mathrm{X}_{2}\right)$, Perception of Respondents about KVK training for Farm Mechanization $\left(\mathrm{X}_{2}\right)$ had significant and positive and significant association with the change in adoption of horticultural technologies.

Step wise regression results as depicted in table 10.1 showed that two variables only retained in the model, having significant positive association with the change in 
adoption pattern of horticultural technologies. The analysis explained $72.89 \%$ of the total variance.

Multiple regression analysis for change in adoption in income generating activities

From the table 11 it can be observed that seven independent variables, namely Extent of training received in horticulture.

Extent of training received in seed science $\left(\mathrm{X}_{1}\right)$, Extent of training received in plant protection $\left(\mathrm{X}_{4}\right)$,

Extent of training received in animal husbandry $\left(\mathrm{X}_{5}\right)$, Perception of Respondents about KVK Training for Income Generating Activity $\left(\mathrm{X}_{7}\right)$, Perception of Respondents about KVK Training for Better Livestock management $\left(\mathrm{X}_{8}\right)$, Perception of Respondents about KVK training for Farm Mechanization $\left(\mathrm{X}_{9}\right)$ had significant and positive association with the change in adoption in income generating activities.

As the multiple regressions analysis explained more that $73 \%$ of the total variance, result of step wise regression was not found better in this case and hence excluded from the purview of analysis.

Association of different factors with extent of training received in different broad areas

For these section five broad areas, namely, Seed Science, Agronomy, Horticulture, Plant Protection and Animal Husbandry have been considered.

Eleven factors have been taken in the factor analysis separately for each broad area. On the basis of scree plot dimensionality had been reduced.

\section{Seed science}

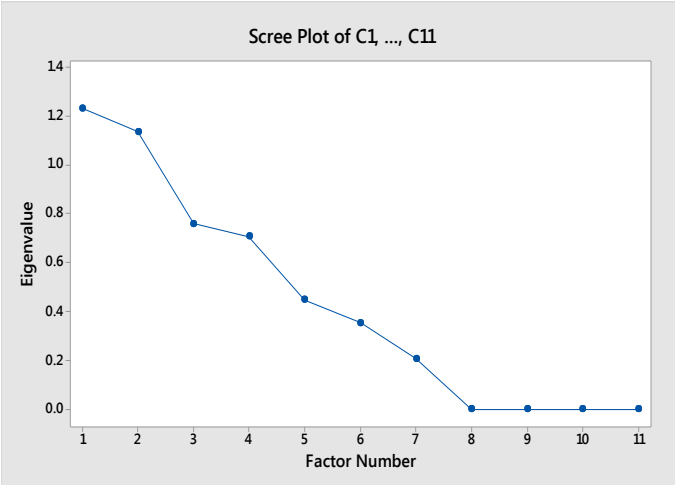

On the basis of factor loadings two factors with highest loadings have been selected. It is found from the table 12 that Factor 1 is primarily anchored by six variables namely, family members, cosmoploiteness, media exposure, social participation, land holdings and annual income. Factor 2 is found to be anchored by age, education, family members, cosmopoliteness, land holdings and material possessions. Factor 3 is anchored by media exposure. Factor 4 is mostly represented by education, family education and social participation. Factor 5 is anchored by age, family education and material possession.

\section{Agronomy}

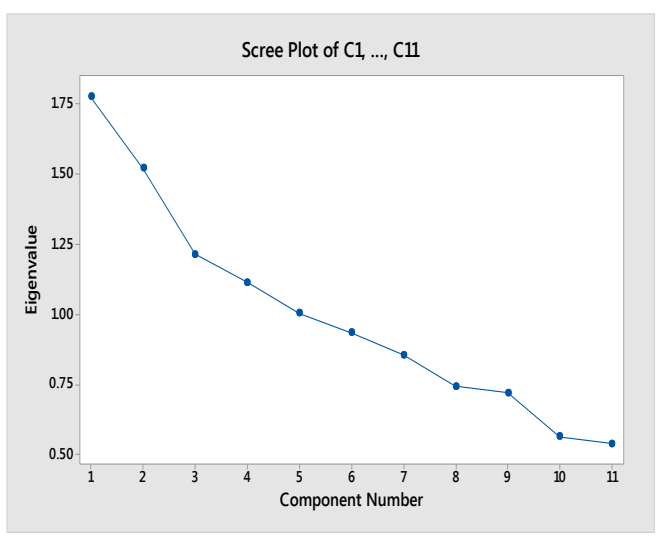

\section{Scree plot of agronomy}

On the basis of factor loadings two factors with highest loadings have been selected. It is found from the table 13 that Factor 1 is 
primarily anchored by seven variables namely, education, family members, cosmopoliteness, media exposure, social participation land holdings and annual income. Factor 2 is found to be anchored by age and annual income. Factor 3 is anchored by media exposure. Factor 4 is mostly represented by family members, land holdings and material possession. Factor 5 is anchored by age, education, family education, social participation and material possession.

\section{Horticulture}

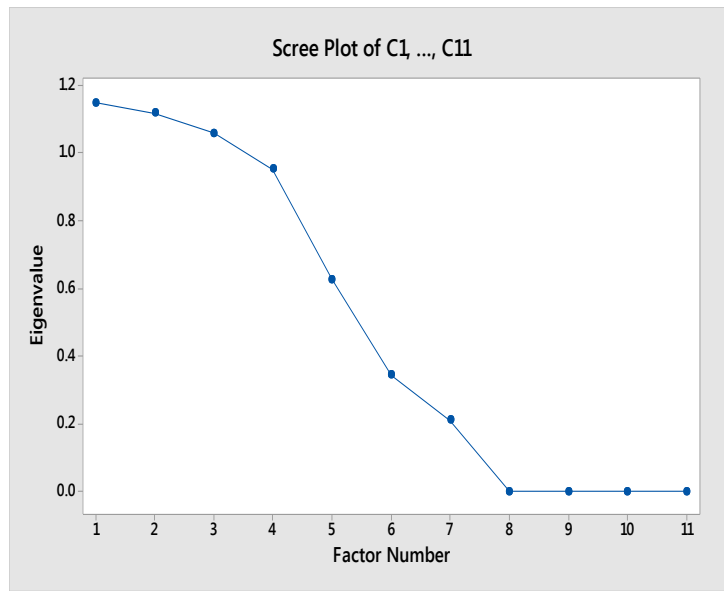

\section{Scree plot of horticulture}

On the basis of factor loadings two factors with highest loadings have been selected. It is found from the table 14 that Factor is primarily anchored by four variables namely, age, education, family members and income. Factor 3 is found to be anchored by cosmopoliteness, media exposure, social participation and land holding.

Similarly factor four is anchored by family education and material possession. Factor five is mostly represented by age and family education. Factor six is anchored by family members, media exposure and land holding. Lastly factor seven is represented by education, cosmopoliteness, social participation, material possession and annual income.

\section{Plant protection}

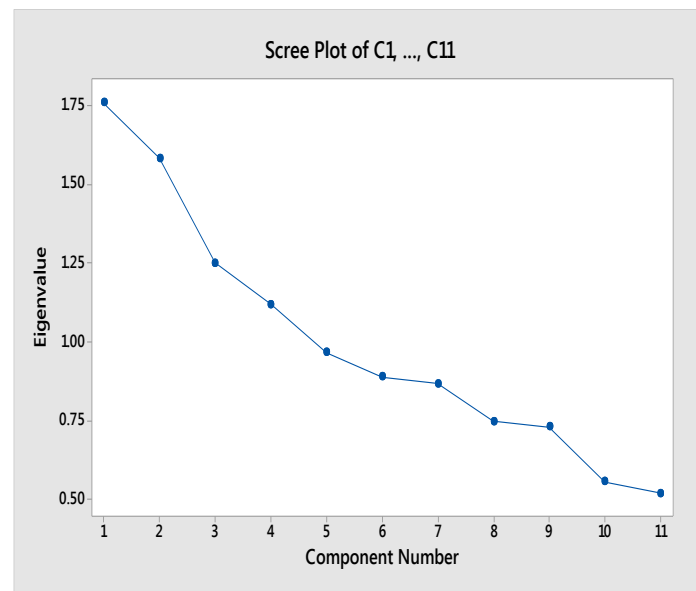

\section{Scree plot of plant protection}

On the basis of factor loadings two factors with highest loadings have been selected. It is found from the table 15 that Factor 1 is primarily anchored by seven variables namely, age, education, family members, cosmopoliteness, social participation land holdings and material possession. Factor 3 is anchored by age, education, family education, social participation and land holdings. Factor 4 is mostly represented by family members, cosmopoliteness, and media exposure and land holdings. Factor 5 is anchored by media exposure.

\section{Animal Husbandry}

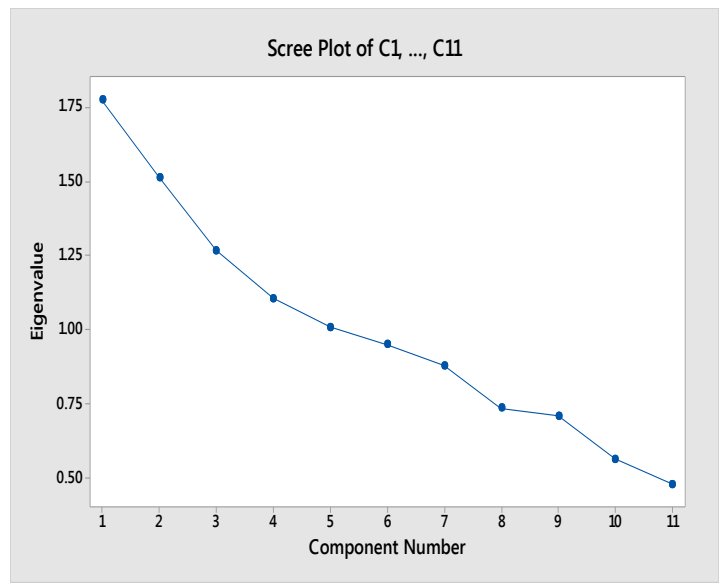


Table.1

$(\mathbf{n}=120)$

\begin{tabular}{|l|c|c|c|c|c|}
\hline \multirow{2}{*}{$\begin{array}{c}\text { Perception Index } \\
\text { (PI) }\end{array}$} & Haringhata Block & Ranaghat Block & Chakdaha Block & Total & Percentage \\
\hline 0-25(Low) & 0 & 0 & 0 & 0 & 0 \\
\hline $\mathbf{2 6 - 5 0}$ (Med) & 11 & 8 & 0 & 19 & 15.83 \\
\hline $\mathbf{5 1 - 7 5}$ (Semi med) & 17 & 16 & 5 & 38 & 31.66 \\
\hline $\mathbf{7 6 - 1 0 0}$ (High) & 12 & 16 & 35 & 66 & 55 \\
\hline
\end{tabular}

Table.2

$(\mathbf{n}=120)$

\begin{tabular}{|l|c|c|c|c|c|}
\hline \multicolumn{1}{|c|}{$\begin{array}{c}\text { Perception Index } \\
\text { (PI) }\end{array}$} & Distribution of the Respondent \\
\hline H-25(Low) & 0 & 0 & 0 & 0 & 0 \\
\hline $\mathbf{2 6 - 5 0}($ Med) & 14 & 13 & 8 & 35 & 29.16 \\
\hline $\mathbf{5 1 - 7 5}$ (Semi-med) & 12 & 12 & 14 & 38 & 31.66 \\
\hline $\mathbf{7 6 - 1 0 0}$ (High) & 14 & 15 & 18 & 47 & 39.16 \\
\hline
\end{tabular}

Table.3

$(\mathbf{n}=120)$

\begin{tabular}{|l|c|c|c|c|c|}
\hline \multirow{2}{*}{$\begin{array}{c}\text { Perception Index } \\
\text { (PI) }\end{array}$} & \multicolumn{5}{|c|}{ Distribution of the Respondent } \\
\cline { 2 - 6 } & Haringhata Block & Ranaghat Block & Chakdaha Block & Total & Percentage \\
\hline $\mathbf{0 - 2 5}($ Low) & 0 & 0 & 0 & 0 & 0 \\
\hline $\mathbf{2 6 - 5 0}($ Med) & 4 & 7 & 0 & 11 & 9.1 \\
\hline $\mathbf{5 1 - 7 5}$ (Semi-med) & 17 & 21 & 10 & 48 & 40 \\
\hline $\mathbf{7 6 - 1 0 0}($ High) & 19 & 12 & 30 & 61 & 50.83 \\
\hline
\end{tabular}

Table.4

$(\mathbf{n}=120)$

\begin{tabular}{|l|c|c|c|c|c|}
\hline \multirow{2}{*}{$\begin{array}{c}\text { Perception Index } \\
(\text { PI) }\end{array}$} & \multicolumn{5}{|c|}{ Distribution of the Respondent } \\
\cline { 2 - 6 } & Haringhata Block & Ranaghat Block & Chakdaha Block & Total & Percentage \\
\hline $\mathbf{0 - 2 5}($ Low) & 0 & 0 & 0 & 0 & 0 \\
\hline $\mathbf{2 6 - 5 0}($ Med) & 11 & 6 & 3 & 20 & 16.66 \\
\hline $\mathbf{5 1 - 7 5}$ (Semi-med) & 15 & 15 & 15 & 45 & 37.5 \\
\hline $\mathbf{7 6 - 1 0 0}($ High) & 14 & 19 & 22 & 55 & 45.83 \\
\hline
\end{tabular}

Table.5

$(\mathbf{n}=120)$

\begin{tabular}{|l|c|c|c|c|c|}
\hline \multirow{2}{*}{ Perception Index } & \multicolumn{4}{|c|}{ Distribution of the Respondent } \\
\cline { 2 - 6 } & $\begin{array}{c}\text { Haringhata } \\
\text { Block }\end{array}$ & Ranaghat Block & Chakdaha Block & Total & Percentage \\
\hline 0-25(Low) & 0 & 0 & 0 & 0 & 0 \\
\hline $\mathbf{2 6 - 5 0}$ (Med) & 5 & 9 & 1 & 15 & 12.5 \\
\hline $\mathbf{5 1 - 7 5}$ (Semi-med) & 15 & 18 & 13 & 46 & 38.33 \\
\hline $\mathbf{7 6 - 1 0 0}$ (High) & 20 & 13 & 26 & 59 & 49.16 \\
\hline
\end{tabular}


Table.6

\begin{tabular}{|c|c|c|c|c|}
\hline Term & Coef & SE Coef & T-Value & P- Value \\
\hline Constant & 310 & 130 & 2.38 & 0.019 \\
\hline$\left(X_{1}\right)$ Extent of training received in Seed Science & 0.927 & 0.800 & 1.16 & $0.049 * *$ \\
\hline$\left(X_{2}\right)$ Extent of training received in Agronomy & 1.379 & 0.973 & 1.42 & $0.039 * *$ \\
\hline$\left(\mathrm{X}_{3}\right)$ Extent of training received in Horticulture & 0.105 & 0.524 & 0.20 & 0.841 \\
\hline$\left(\mathrm{X}_{4}\right)$ Extent of training received in Plant Protection & -0.085 & 0.658 & -0.13 & 0.898 \\
\hline$\left(\mathrm{X}_{5}\right)$ Extent of training received in Animal Husbandry & 0.19 & 1.09 & 0.17 & 0.862 \\
\hline $\begin{array}{l}\left(\mathbf{X}_{6}\right) \text { Perception of Respondents about KVK Training in Increasing } \\
\text { Knowledge and Skill about Agricultural Technologies }\end{array}$ & -0.424 & 0.491 & -0.86 & 0.390 \\
\hline $\begin{array}{l}\left(X_{7}\right) \text { Perception of Respondents about KVK Training for Income Generating } \\
\text { Activity }\end{array}$ & -0.220 & 0.492 & -0.45 & 0.656 \\
\hline $\begin{array}{l}\left(\mathrm{X}_{8}\right) \text { Perception of Respondents about KVK Training for Better Livestock } \\
\text { management }\end{array}$ & -0.492 & 0.480 & -1.02 & 0.308 \\
\hline$\left(\mathrm{X}_{9}\right)$ Perception of Respondents about KVK training for Farm Mechanization & 0.315 & 0.629 & 0.50 & 0.617 \\
\hline ( $\left.\mathbf{X}_{10}\right)$ Perception of Respondents about KVK training on New Technology & -0.005 & 0.499 & -0.01 & 0.992 \\
\hline $\begin{array}{l}\left(\mathrm{X}_{11}\right) \text { Perception of Respondents about KVK training for overall Improvement } \\
\text { of Socio- Economic Condition }\end{array}$ & 0.150 & 0.543 & 0.28 & 0.783 \\
\hline
\end{tabular}

Table.6.1 Results of stepwise regression

\begin{tabular}{|c|c|c|c|c|}
\hline Term & Coef & SE Coef & T- Value & P- Value \\
\hline Constant & 275.5 & 63.4 & 4.34 & 0.000 \\
\hline Extent of training received in Seed science & -0.989 & 0.749 & -1.32 & $0.009 *$ \\
\hline Extent of training received in Agronomy & -1.340 & 0.930 & -1.44 & $0.002 *$ \\
\hline * Significant @ 1\% level & \multicolumn{4}{|c|}{ R-sq $43.33 \% \quad$ R-sq $($ adj $)=32.83 \%$} \\
\hline
\end{tabular}

Table.7

\begin{tabular}{|c|c|c|c|c|}
\hline Term & Coef & SE Coef & T- Value & P- Value \\
\hline Constant & -110 & 176 & -0.63 & 0.532 \\
\hline$\left(X_{1}\right)$ Extent of training received in Seed Science & 2.10 & 1.08 & 1.94 & $0.045 * *$ \\
\hline$\left(X_{2}\right)$ Extent of training received in Agronomy & -0.25 & 1.31 & -0.19 & 0.847 \\
\hline$\left(X_{3}\right)$ Extent of training received in Horticulture & 0.033 & 0.707 & 0.05 & 0.963 \\
\hline$\left(X_{4}\right)$ Extent of training received in Plant Protection & -0.563 & 0.890 & -0.63 & 0.528 \\
\hline$\left(X_{5}\right)$ Extent of training received in Animal Husbandry & 2.45 & 1.47 & 1.67 & $0.037 * *$ \\
\hline $\begin{array}{l}\text { (X) Perception of Respondents about KVK Training in } \\
\text { Increasing Knowledge and Skill about Agricultural Technologies }\end{array}$ & 0.095 & 0.663 & 0.14 & 0.887 \\
\hline $\begin{array}{l}\left(X_{7}\right) \text { Perception of Respondents about KVK Training for Income } \\
\text { Generating Activity }\end{array}$ & -1.140 & 0.665 & -1.72 & 0.089 \\
\hline $\begin{array}{l}\left(X_{8}\right) \text { Perception of Respondents about KVK Training for Better } \\
\text { Livestock management }\end{array}$ & 0.341 & 0.649 & 0.53 & 0.600 \\
\hline $\begin{array}{l}\text { (X) Perception of Respondents about KVK training for Farm } \\
\text { Mechanization }\end{array}$ & 0.271 & 0.850 & 0.32 & 0.751 \\
\hline $\begin{array}{l}\left(X_{10}\right) \text { Perception of Respondents about KVK training on New } \\
\text { Technology }\end{array}$ & 0.724 & 0.674 & 1.07 & $0.015 * *$ \\
\hline $\begin{array}{l}\left(\mathrm{X}_{11}\right) \text { Perception of Respondents about KVK training for overall } \\
\text { Improvement of Socio- Economic Condition }\end{array}$ & 0.958 & 0.734 & 1.31 & 0.095 \\
\hline \multicolumn{5}{|l|}{ ** Significant @ 5\% level $\quad$ R-sq = 56.32\% } \\
\hline
\end{tabular}


Table.7.1 Results of Stepwise Regression

\begin{tabular}{|c|c|c|c|c|}
\hline Term & Coef & SE Coef & T- Value & P-Value \\
\hline Constant & -127 & 122 & -1.05 & 0.298 \\
\hline Extent of training received in Seed science & 1.98 & 1.04 & 1.90 & $0.041 * *$ \\
\hline Extent of training received in Animal husbandry & 2.46 & 1.41 & 1.74 & $0.004 *$ \\
\hline $\begin{array}{l}\text { Perception of Respondents about KVK Training for Income } \\
\text { Generating Activity }\end{array}$ & 1.061 & 0.634 & 1.67 & $0.047 * *$ \\
\hline $\begin{array}{l}\text { Perception of Respondents about KVK training on New } \\
\text { Technology }\end{array}$ & 0.896 & 0.609 & 1.47 & $0.044 * *$ \\
\hline $\begin{array}{l}\text { Perception of Respondents about KVK training for overall } \\
\text { Improvement of Socio- Economic Condition }\end{array}$ & 1.008 & 0.665 & 1.64 & $0.105 * *$ \\
\hline
\end{tabular}

Table.8

\begin{tabular}{|c|c|c|c|c|}
\hline Term & Coef & SE Coef & T- Value & P-Value \\
\hline Constant & 121.8 & 53.5 & 2.28 & 0.025 \\
\hline$\left(X_{1}\right)$ Extent of training received in Seed Science & -0.050 & 0.329 & -0.15 & 0.879 \\
\hline$\left(\mathbf{X}_{2}\right)$ Extent of training received in Agronomy & -0.536 & 0.400 & -1.34 & $0.042 * *$ \\
\hline$\left(\mathbf{X}_{3}\right)$ Extent of training received in Horticulture & -0.429 & 0.215 & -0.15 & $0.049 * *$ \\
\hline$\left(\mathbf{X}_{4}\right)$ Extent of training received in Plant Protection & -0.425 & 0.270 & -1.57 & $0.009 *$ \\
\hline$\left(X_{5}\right)$ Extent of training received in Animal Husbandry & 0.446 & 0.446 & 1.00 & 0.319 \\
\hline $\begin{array}{l}\text { (X) Perception of Respondents about KVK Training in } \\
\text { Increasing Knowledge and Skill about Agricultural Technologies }\end{array}$ & -0.369 & 0.202 & -1.83 & $0.040 * *$ \\
\hline $\begin{array}{l}\left(\mathbf{X}_{7}\right) \text { Perception of Respondents about KVK Training for Income } \\
\text { Generating Activity }\end{array}$ & -0.189 & 0.202 & -0.94 & 0.351 \\
\hline $\begin{array}{l}\text { (X) Perception of Respondents about KVK Training for Better } \\
\text { Livestock management }\end{array}$ & 0.034 & 0.197 & 0.17 & 0.865 \\
\hline $\begin{array}{l}\text { (X) Perception of Respondents about KVK training for Farm } \\
\text { Mechanization }\end{array}$ & 0.140 & 0.258 & 0.54 & 0.589 \\
\hline $\begin{array}{l}\left(X_{10}\right) \text { Perception of Respondents about KVK training on New } \\
\text { Technology }\end{array}$ & -0.006 & 0.205 & -0.03 & 0.978 \\
\hline $\begin{array}{l}\left(\mathbf{X}_{11}\right) \text { Perception of Respondents about KVK training for overall } \\
\text { Improvement of Socio- Economic Condition }\end{array}$ & 0.156 & 0.223 & 0.70 & 0.486 \\
\hline
\end{tabular}

Table.8.1 Results of Stepwise Regression

\begin{tabular}{|l|c|c|c|c|}
\hline \multicolumn{1}{|c|}{ Term } & Coef & SE Coef & T- Value & P- Value \\
\hline Constant & 150.6 & 35.1 & 4.29 & 0.000 \\
\hline Extent of training received in horticulture & -0.374 & 0.204 & -1.83 & $\mathbf{0 . 0 7 0}$ \\
\hline Extent of training received in Plant protection & -0.439 & 0.263 & -1.67 & $\mathbf{0 . 0 9 8}$ \\
\hline Extent of training received in Agronomy & -0.561 & 0.387 & -1.45 & $\mathbf{0 . 1 5 0}$ \\
\hline $\begin{array}{l}\text { Perception of Respondents about KVK Training in } \\
\text { Increasing Knowledge and Skill about Agricultural } \\
\text { Technologies }\end{array}$ & -0.320 & 0.188 & -1.71 & $\mathbf{0 . 0 9 1}$ \\
\hline \multicolumn{1}{|c|}{} & & & \\
\hline
\end{tabular}


Table.9

\begin{tabular}{|c|c|c|c|c|}
\hline Term & Coef & SE Coef & T- Value & P- Value \\
\hline Constant & 133 & 165 & 0.81 & 0.422 \\
\hline$\left(\mathrm{X}_{1}\right)$ Extent of training received in Seed Science & 1.39 & 1.01 & 1.37 & $0.043 * *$ \\
\hline$\left(\mathrm{X}_{2}\right)$ Extent of training received in Agronomy & 0.98 & 1.23 & 0.80 & 0.428 \\
\hline$\left(\mathbf{X}_{3}\right)$ Extent of training received in Horticulture & 0.082 & 0.667 & 0.12 & 0.902 \\
\hline$\left(\mathrm{X}_{4}\right)$ Extent of training received in Plant Protection & -0.404 & 0.838 & -0.48 & 0.630 \\
\hline$\left(\mathbf{X}_{5}\right)$ Extent of training received in Animal Husbandry & 1.23 & 1.37 & 0.89 & $\mathbf{0 . 0 3 3} * *$ \\
\hline $\begin{array}{l}\left(\mathrm{X}_{6}\right) \text { Perception of Respondents about KVK Training in Increasing Knowledge and } \\
\text { Skill about Agricultural Technologies }\end{array}$ & 0.577 & 0.626 & 0.92 & $0.039 * *$ \\
\hline$\left(\mathrm{X}_{7}\right)$ Perception of Respondents about KVK Training for Income Generating Activity & 0.473 & 0.625 & 0.76 & 0.451 \\
\hline $\begin{array}{l}\left(\mathbf{X}_{8}\right) \text { Perception of Respondents about KVK Training for Better Livestock } \\
\text { management }\end{array}$ & 1.200 & 0.612 & 1.96 & $0.042 * *$ \\
\hline$\left(\mathrm{X}_{9}\right)$ Perception of Respondents about KVK training for Farm Mechanization & -0.575 & 0.801 & -0.72 & 0.475 \\
\hline$\left(\mathbf{X}_{10}\right)$ Perception of Respondents about KVK training on New Technology & -0.072 & 0.634 & -0.11 & 0.910 \\
\hline $\begin{array}{l}\left(\mathbf{X}_{11}\right) \text { Perception of Respondents about KVK training for overall Improvement of } \\
\text { Socio- Economic Condition }\end{array}$ & 0.169 & 0.684 & 0.25 & 0.805 \\
\hline
\end{tabular}

Table.9.1 Stepwise regression analysis for Change in Adoption Crop Production Technologies

\begin{tabular}{|l|c|c|c|c|}
\hline \multicolumn{1}{|c|}{ Term } & Coef & SE Coef & T- Value & P- Value \\
\hline Constant & 182.2 & 64.7 & 2.81 & 0.006 \\
\hline $\begin{array}{l}\text { Extent of training received in Seed science Seed } \\
\text { science }\end{array}$ & 1.458 & 0.952 & 1.53 & $0.028^{* *}$ \\
\hline $\begin{array}{l}\text { Extent of training received in Income generating } \\
\text { activity }\end{array}$ & 1.157 & 0.587 & 1.97 & $0.041^{* *}$ \\
\hline \multicolumn{2}{|c|}{ *ignificant @ 5\% level } & & & \\
\hline
\end{tabular}

Table.10

\begin{tabular}{|c|c|c|c|c|}
\hline Term & Coef & SE Coef & T- Value & P- Value \\
\hline Constant & 124 & 127 & 0.98 & 0.328 \\
\hline$\left(\mathrm{X}_{1}\right)$ Extent of training received in Seed Science & -0.310 & 0.776 & -0.40 & 0.690 \\
\hline$\left(\mathbf{X}_{2}\right)$ Extent of training received in Agronomy & 1.451 & 0.942 & 1.54 & $0.026 * *$ \\
\hline$\left(\mathrm{X}_{3}\right)$ Extent of training received in Horticulture & 0.473 & 0.512 & 0.92 & $0.048 * *$ \\
\hline$\left(\mathbf{X}_{4}\right)$ Extent of training received in Plant Protection & 0.538 & 0.643 & 0.84 & 0.405 \\
\hline ( $\mathrm{X}_{5}$ ) Extent of training received in Animal Husbandry & -0.34 & 1.05 & -0.32 & 0.749 \\
\hline $\begin{array}{l}\left(\mathbf{X}_{6}\right) \text { Perception of Respondents about KVK Training in Increasing } \\
\text { Knowledge and Skill about Agricultural Technologies }\end{array}$ & -0.308 & 0.481 & -0.64 & 0.524 \\
\hline $\begin{array}{l}\left(\mathbf{X}_{7}\right) \text { Perception of Respondents about KVK Training for Income Generating } \\
\text { Activity }\end{array}$ & -0.287 & 0.480 & -0.60 & 0.551 \\
\hline $\begin{array}{l}\left(\mathbf{X}_{8}\right) \text { Perception of Respondents about KVK Training for Better Livestock } \\
\text { management }\end{array}$ & 0.560 & 0.470 & 1.19 & $0.035 * *$ \\
\hline $\begin{array}{l}\text { (X) Perception of Respondents about KVK training for Farm } \\
\text { Mechanization }\end{array}$ & 0.294 & 0.615 & 0.48 & $\mathbf{0 . 0 3 3} * *$ \\
\hline$\left(X_{10}\right)$ Perception of Respondents about KVK training on New Technology & -0.247 & 0.487 & -0.51 & 0.612 \\
\hline $\begin{array}{l}\left(\mathbf{X}_{11}\right) \text { Perception of Respondents about KVK training for overall } \\
\text { Improvement of Socio- Economic Condition }\end{array}$ & 0.143 & 0.525 & 0.27 & 0.786 \\
\hline
\end{tabular}


Table.10.1 Stepwise regression analysis for Change in Horticultural Technologies

\begin{tabular}{|l|c|c|c|c|}
\hline \multicolumn{1}{|c|}{ Term } & Coef & SE Coef & T- Value & P-Value \\
\hline Constant & 99.1 & 60.9 & 1.63 & 0.107 \\
\hline Extent of training received in Agronomy & 1.517 & 0.907 & 1.63 & $0.047 * *$ \\
\hline Extent of training received in Income generating activity & -0.573 & 0.450 & -1.27 & $0.010^{*}$ \\
\hline \multicolumn{2}{|c|}{ *Significant @ 1 \% level ** Significant @ 5\% level } & \multicolumn{2}{|c|}{ R-sq = 77.79\% R-sq(adj) 72.89\% } \\
\hline
\end{tabular}

\section{Table.11}

\begin{tabular}{|c|c|c|c|c|}
\hline Term & Coef & SE Coef & T- Value & P- Value \\
\hline Constant & 90 & 112 & 0.80 & 0.424 \\
\hline$\left(X_{1}\right)$ Extent of training received in Seed Science & 0.786 & 0.689 & 1.14 & $0.056^{* *}$ \\
\hline$\left(\mathrm{X}_{2}\right)$ Extent of training received in Agronomy & -0.092 & 0.836 & -0.11 & 0.912 \\
\hline$\left(X_{3}\right)$ Extent of training received in Horticulture & 0.270 & 0.455 & 0.59 & $0.054 * *$ \\
\hline$\left(\mathbf{X}_{4}\right)$ Extent of training received in Plant Protection & 0.115 & 0.571 & 0.20 & $0.041 * *$ \\
\hline$\left(X_{5}\right)$ Extent of training received in Animal Husbandry & 0.097 & 0.935 & 0.10 & $0.017 * *$ \\
\hline $\begin{array}{l}\left(\mathbf{X}_{6}\right) \text { Perception of Respondents about KVK Training in Increasing } \\
\text { Knowledge and Skill about Agricultural Technologies }\end{array}$ & -0.062 & 0.427 & -0.15 & 0.884 \\
\hline $\begin{array}{l}\left(\mathbf{X}_{7}\right) \text { Perception of Respondents about KVK Training for Income } \\
\text { Generating Activity }\end{array}$ & 0.412 & 0.426 & 0.97 & $0.035 * *$ \\
\hline $\begin{array}{l}\text { (X) Perception of Respondents about KVK Training for Better } \\
\text { Livestock management }\end{array}$ & 0.202 & 0.417 & 0.48 & $0.029 * *$ \\
\hline $\begin{array}{l}\text { (X) Perception of Respondents about KVK training for Farm } \\
\text { Mechanization }\end{array}$ & 0.383 & 0.546 & 0.70 & $0.044 * *$ \\
\hline $\begin{array}{l}\left(X_{10}\right) \text { Perception of Respondents about KVK training on New } \\
\text { Technology }\end{array}$ & 0.171 & 0.432 & 0.40 & 0.693 \\
\hline $\begin{array}{l}\left(\mathrm{X}_{11}\right) \text { Perception of Respondents about KVK training for overall } \\
\text { Improvement of Socio- Economic Condition }\end{array}$ & 0.047 & 0.466 & 0.10 & 0.920 \\
\hline **Significant @ 5\% level R-sq & $9 \% \mathrm{R}$ & dj) $=73.1$ & & \\
\hline
\end{tabular}

Table.12

\begin{tabular}{|l|c|c|c|c|c|c|}
\hline \multicolumn{1}{|c|}{ Variables } & Factor 1 & Factor 2 & Factor 3 & Factor 4 & Factor 5 & Communality \\
\hline Age & -0.038 & $\mathbf{0 . 6 7 2}$ & -0.240 & 0.168 & $\mathbf{0 . 2 8 8}$ & 0.622 \\
\hline Education & 0.090 & $\mathbf{0 . 1 9 8}$ & -0.487 & $\mathbf{0 . 1 2 2}$ & 0.033 & 0.301 \\
\hline Family Education & 0.018 & -0.043 & -0.036 & $\mathbf{0 . 0 4 4}$ & $\mathbf{0 . 4 7 4}$ & 0.230 \\
\hline Family members & $\mathbf{0 . 1 1 4}$ & $\mathbf{0 . 5 5 3}$ & 0.018 & -0.155 & -0.162 & 0.369 \\
\hline Cosmopliteness & $\mathbf{0 . 9 2 3}$ & $\mathbf{0 . 0 9 7}$ & -0.194 & -0.046 & -0.043 & 0.903 \\
\hline Media Exposure & $\mathbf{0 . 2 6 5}$ & -0.020 & $\mathbf{0 . 0 5 6}$ & -0.070 & -0.326 & 0.185 \\
\hline Social Participation & $\mathbf{0 . 1 6 0}$ & 0.016 & -0.161 & $\mathbf{0 . 3 0 2}$ & 0.149 & 0.165 \\
\hline Land Holdings & $\mathbf{0 . 2 0 9}$ & $\mathbf{0 . 1 0 4}$ & -0.170 & -0.599 & -0.016 & 0.442 \\
\hline Material Possession & -0.052 & $\mathbf{0 . 0 6 1}$ & -0.347 & -0.126 & $\mathbf{0 . 1 8 4}$ & 0.177 \\
\hline Annual Income & $\mathbf{0 . 0 7 6}$ & -0.103 & -0.263 & -0.016 & -0.012 & 0.086 \\
\hline
\end{tabular}


Table.13

\begin{tabular}{|l|c|c|c|c|c|c|}
\hline \multicolumn{1}{|c|}{ Variables } & Factor 1 & Factor 2 & Factor 3 & Factor 4 & Factor 5 & Communality \\
\hline Age & -0.077 & -0.542 & -0.323 & -0.122 & $\mathbf{0 . 2 5 6}$ & 0.485 \\
\hline Education & $\mathbf{0 . 1 0 8}$ & -0.191 & -0.504 & -0.098 & $\mathbf{0 . 0 2 1}$ & 0.312 \\
\hline Family Education & -0.049 & $\mathbf{0 . 0 6 2}$ & -0.093 & -0.031 & $\mathbf{0 . 4 2 7}$ & 0.198 \\
\hline Family members & $\mathbf{0 . 1 2 9}$ & -0.652 & 0.043 & $\mathbf{0 . 1 5 8}$ & -0.091 & 0.476 \\
\hline Cosmopliteness & $\mathbf{0 . 7 3 1}$ & -0.103 & -0.193 & 0.111 & 0.029 & 0.596 \\
\hline Media Exposure & $\mathbf{0 . 3 6 7}$ & 0.009 & $\mathbf{0 . 0 9 7}$ & 0.050 & -0.297 & 0.235 \\
\hline Social Participation & $\mathbf{0 . 2 1 5}$ & 0.001 & -0.159 & -0.295 & $\mathbf{0 . 2 5 2}$ & 0.222 \\
\hline Land Holdings & $\mathbf{0 . 2 1 3}$ & -0.080 & -0.144 & $\mathbf{0 . 6 4 0}$ & 0.004 & 0.482 \\
\hline Material Possession & -0.081 & -0.030 & -0.363 & $\mathbf{0 . 1 3 5}$ & $\mathbf{0 . 1 1 0}$ & 0.170 \\
\hline Annual Income & $\mathbf{0 . 1 0 3}$ & $\mathbf{0 . 1 0 8}$ & -0.233 & 0.024 & -0.000 & 0.077 \\
\hline
\end{tabular}

Table.14

\begin{tabular}{|l|c|c|c|c|c|c|c|c|}
\hline \multicolumn{1}{|c|}{ Variables } & Factor 1 & Factor 2 & Factor 3 & Factor 4 & Factor 5 & Factor 6 & Factor 7 & Communality \\
\hline Age & $\mathbf{0 . 8 2 3}$ & 0.102 & -0.103 & 0.094 & $\mathbf{1 . 1 3 4}$ & -0.160 & 0.008 & 0.751 \\
\hline Education & $\mathbf{0 . 3 1 4}$ & -0.088 & 0.080 & 0.101 & 0.031 & -0.108 & $\mathbf{0 . 3 2 3}$ & 0.240 \\
\hline Family Education & 0.002 & 0.045 & -0.051 & $\mathbf{0 . 0 4 6}$ & $\mathbf{0 . 6 6 1}$ & -0.076 & 0.016 & 0.450 \\
\hline Family members & $\mathbf{0 . 4 3 0}$ & 0.047 & 0.155 & -0.031 & -0.113 & $\mathbf{0 . 2 2 4}$ & -0.066 & 0.279 \\
\hline Cosmopliteness & 0.147 & 0.096 & $\mathbf{0 . 8 6 6}$ & -0.010 & 0.047 & -0.044 & $\mathbf{0 . 2 3 7}$ & 0.841 \\
\hline Media Exposure & -0.077 & -0.022 & $\mathbf{0 . 3 4 3}$ & -0.017 & -0.232 & $\mathbf{0 . 0 4 3}$ & -0.088 & 0.188 \\
\hline Social Participation & 0.095 & -0.084 & $\mathbf{0 . 1 1 9}$ & 0.029 & 0.106 & -0.434 & $\mathbf{0 . 1 1 3}$ & 0.244 \\
\hline Land Holdings & 0.106 & 0.053 & $\mathbf{0 . 2 8 7}$ & 0.100 & 0.020 & $\mathbf{0 . 4 2 9}$ & 0.102 & 0.301 \\
\hline Material Possession & 0.084 & 0.015 & 0.013 & $\mathbf{0 . 9 8 6}$ & 0.068 & 0.038 & $\mathbf{0 . 1 1 9}$ & 1.000 \\
\hline Annual Income & $\mathbf{0 . 0 3 8}$ & -0.024 & 0.030 & 0.034 & 0.016 & -0.005 & $\mathbf{0 . 4 0 2}$ & 0.166 \\
\hline
\end{tabular}

Table.15

\begin{tabular}{|l|c|c|c|c|c|c|}
\hline \multicolumn{1}{|c|}{ Variables } & Factor 1 & Factor 2 & Factor 3 & Factor 4 & Factor 5 & Communality \\
\hline Age & $\mathbf{0 . 8 2 4}$ & 0.016 & $\mathbf{0 . 3 0 3}$ & -0.159 & -0.142 & 0.816 \\
\hline Education & $\mathbf{0 . 2 4 5}$ & -0.113 & $\mathbf{0 . 0 2 1}$ & -0.108 & -0.366 & 0.218 \\
\hline Family Education & -0.033 & -0.039 & $\mathbf{0 . 3 7 2}$ & -0.103 & -0.116 & 0.165 \\
\hline Family members & $\mathbf{0 . 4 7 3}$ & -0.103 & -0.215 & $\mathbf{0 . 1 9 2}$ & 0.033 & 0.318 \\
\hline Cosmopliteness & $\mathbf{0 . 1 0 9}$ & -0.883 & -0.145 & $\mathbf{0 . 0 0 8}$ & -0.178 & 0.844 \\
\hline Media Exposure & -0.021 & -0.244 & -0.336 & $\mathbf{0 . 0 7 5}$ & $\mathbf{0 . 0 8 0}$ & 0.184 \\
\hline Social Participation & $\mathbf{0 . 0 5 5}$ & -0.149 & $\mathbf{0 . 0 4 5}$ & -0.374 & -0.184 & 0.201 \\
\hline Land Holdings & $\mathbf{0 . 0 8 1}$ & -0.242 & -0.016 & $\mathbf{0 . 5 5 2}$ & -0.198 & 0.409 \\
\hline Material Possession & $\mathbf{0 . 1 0 3}$ & 0.040 & $\mathbf{0 . 1 3 7}$ & 0.094 & -0.380 & 0.184 \\
\hline Annual Income & -0.077 & -0.066 & -0.041 & -0.033 & -0.316 & 0.113 \\
\hline
\end{tabular}

Table.16

\begin{tabular}{|l|c|c|c|c|c|c|}
\hline Variables & Factor 1 & Factor 2 & Factor 3 & Factor 4 & Factor 5 & Communality \\
\hline Age & $\mathbf{0 . 8 7 7}$ & 0.122 & 0.121 & -0.260 & $\mathbf{0 . 1 5 2}$ & 0.890 \\
\hline Education & $\mathbf{0 . 2 3 6}$ & -0.082 & -0.156 & -0.317 & $\mathbf{0 . 0 8 6}$ & 0.195 \\
\hline Family Education & 0.011 & -0.067 & $\mathbf{0 . 0 8 8}$ & -0.312 & $\mathbf{0 . 1 2 9}$ & 0.126 \\
\hline Family members & $\mathbf{0 . 4 3 7}$ & -0.085 & -0.184 & $\mathbf{0 . 1 2 1}$ & -0.208 & 0.290 \\
\hline Cosmopliteness & $\mathbf{0 . 1 1 7}$ & $\mathbf{0 . 0 6 2}$ & -0.778 & -0.153 & 0.002 & 0.647 \\
\hline Media Exposure & -0.036 & $\mathbf{0 . 0 3 9}$ & -0.366 & $\mathbf{0 . 2 3 8}$ & -0.070 & 0.199 \\
\hline Social Participation & 0.051 & $\mathbf{0 . 0 8 2}$ & -0.151 & -0.203 & $\mathbf{0 . 3 7 5}$ & 0.214 \\
\hline Land Holdings & $\mathbf{0 . 0 7 1}$ & $\mathbf{0 . 0 5 8}$ & -0.284 & -0.182 & -0.552 & 0.427 \\
\hline Material Possession & $\mathbf{0 . 0 9 3}$ & 0.035 & $\mathbf{0 . 0 4 2}$ & -0.366 & -0.116 & 0.159 \\
\hline Annual Income & -0.097 & $\mathbf{0 . 1 0 5}$ & -0.113 & -0.231 & $\mathbf{0 . 0 0 9}$ & 0.087 \\
\hline
\end{tabular}




\section{Scree plot of animal husbandry}

On the basis of factor loadings two factors with highest loadings have been selected. It is found from the table 16 that Factor 1 is primarily anchored by six variables namely, age, education, family members, cosmopoliteness, land holdings and material possession. Factor 2 is anchored by cosmopoliteness, media exposure, social participation, land holdings, and annual income. Factor 3 is anchored by family education and material possession. Factor 4 is mostly represented by family members and media exposure. Factor 5 is anchored by age, education, family education, social participation and annual income.

It is concluded that,

Majority of the respondents had high perception about increase in knowledge and skill through KVK training followed by semimedium and medium level of perception

Majority of the respondents had high of perception about KVK training for income generating activity index group followed by semi-medium and medium index group respectively

Majority of the respondents had high perception about KVK training for better livestock management followed by semimedium and medium level of perception.

Majority of the respondents had high level perception about KVK training for farm mechanization followed by semi-medium and medium level of perception.

Majority of the respondents had high of perception regarding getting new technologies form KVK training followed by semi-medium and medium index group.

Majority of the respondents had high perception about KVK training for overall improvement of socio-economic conditions or the respondents followed by semi medium and medium level of perception.

\section{References}

Bowden, R. (1984). Experimental Learning in Agriculture. In training from agricultural development 1982. FAO Economic and Social development series, 26:39-47, 369.

Gorsuch, Richard L. (1983) Factor Analysis. Hillsdale, NJ: Erlbaum

Mishra, B. Mishra, R. and Kanungo, A.P. (2005) Women's access to farm information and technology, Journal of Extn. Edn. Vol. ix and x $(1,2)$ pp 72-77.

Sharma, K.A. and Murthy, A.S. (1971). Training needs as perceived by farmers. Kurukshetra. Vol. 19, No. 15, pp. 11.

Singh, H. and Patel, H.N. (1990). Knowledge level and socio-economic characteristics of content and non-contact farmers. Maharashtra J. Extn. Edu., Vol. XXIV, No. $1 \& 2$, p. $71-72$

Sohal, T.S. (1967).Organizing farmers' Training Report presented at summer institute held at I.A.R.I. New Delhi-12.

\section{How to cite this article:}

Sabyasachi Karak, Subhajit Roy and Siddhartha Dev Mukhopadhyay. 2019. Studies of the Perception of Respondents regarding KVK Training Intervention in Agriculture. Int.J.Curr.Microbiol.App.Sci. 8(02): 1275-1290. doi: https://doi.org/10.20546/ijcmas.2019.802.149 